\title{
Effects of Bradyrhizobium japonicum on nitrogen content in soybean leaves and seeds cultivated on acidic soils
}

\author{
Ben Tshibuyi Kasu-Bandii, ${ }^{1,2}$ Fabien Kitengie Kitengie ${ }^{3}$, Jonas Lwamuguma Bagaluza ${ }^{2}$, Aristote Bwende Nkolo- \\ moni $^{2}$, Emery Kasongo Lenge ${ }^{2}$, Antoine Kanyenga Lubobo ${ }^{2,4}$
}

\author{
${ }^{1}$ National Institute for Agricultural Research and Study (INERA), Kipopo Station, P.O Box 224; Lubumbashi, DR \\ Congo \\ ${ }^{2}$ Faculty of Agricultural Sciences, Université de Lubumbashi, \\ Lubumbashi, DR Congo \\ ${ }^{3}$ Higher Institute of Applied Techniques of Lubumbashi (ISTA-LU), Lubumbashi, DR Congo \\ ${ }^{4}$ International Center for Tropical Agriculture, Harvest Plus, DR Congo \\ * Correspondence: bentshibuyi@gmail.com (Ben Tshibuyi Kasu-Bandi)
}

\begin{abstract}
The legume-rhizobium symbiosis plays an important role in the nitrogen $(\mathrm{N})$ assimilation of plants, more particularly in the humid tropical region where soils are deeply weathered and have poor electrochemical properties. On acidic soils of Haut-Katanga, DR Congo it is not clear how application of Bradyrhizobium japonicum affect $\mathrm{N}$ allocation among soybean organs (e.g., leaves, seeds). Here, we assessed the effect of Bradyrhizobium japonicum on $\mathrm{N}$ content of soybean leaves and seeds cultivated on acidic soils. We conducted two experiments using a split-plot setup with three replicates in two sites (i.e., Kasapa and Kanyameshi). The main plots included three strains of Bradyrhizobium plus the uninoculated control and four varieties of soybean in the subplot. We found that the different strains of Bradyrhizobium did not induce significant effects on the total $\mathrm{N}$ content of soybean leaves and seeds in the Kasapa site. In contrast, Bradyrhizobium affected significantly the $\mathrm{N}$ content of soybean leaves in the Kanyameshi site. We demonstrated that $\mathrm{N}$ content in the soil, which varies between the two sites, positively influences yield and nodulation. We conclude that that the efficiency of the soybean-Bradyrhizobium symbiosis and its influence on the allocation of $\mathrm{N}$ through soybean plants strongly depend on the chemical characteristics of the soil and particularly on the initial levels of $\mathrm{N}$ in the soils.
\end{abstract}

Keywords: Symbiosis, rhizobium, Ferralsol, Haut-Katanga

\section{Introduction}

Constituting one of the major processes of transformation of atmospheric nitrogen $(\mathrm{N})$ into a form that can be assimilated by plants, the biological fixation of $\mathrm{N}$ is an important pathway for $\mathrm{N}$ to enter the biogeochemical cycle (Kaminski, 1991; Graham and Vance, 2003; ICNF, 2009). Nitrogen fixation is a process occurring via a symbiotic association between bacteria of the rhizobium genus and leguminous plants (Graham and Vance, 2003; Vieira et al., 2010). This symbiosis can store up to $65 \%$ of the $\mathrm{N}$ used in the world per year (Sahgal and Johri, 2003).

Given its agronomic, economic and ecological interests, the legume-rhizobium symbiosis is an important component in the humid tropical region (FAO, 2009). Indeed, it is reported that when this symbiosis works well, it can provide adequate $\mathrm{N}$ nutrition to plants and ensure proper production, thus saving farmers the cost of chemical fertilizers and relieving environmental pollution (Faghire et al., 2011). However, this process is subject to several edaphic factors such as temperature variation, salinity, lack of nutrients, metal toxicity or even soil acidity that can affect the physiological state of the host plant or impact 
the microbial community, and thus influence the rate of $\mathrm{N}$ fixation (Zahran, 1999; Dita et al., 2006; Borucki and Sujkowska, 2008; Cesar et al., 2011; Emamverdian et al., 2015).

In the humid tropical zone in general and the city of Lubumbashi and its surroundings in particular, soil acidity remains one of the most limiting factors of agricultural productivity (Ngongo and Kasongo 2004; Ngongo and Mukalay, 2004) and particularly when N nutrition is provided by the symbiotic fixation. Soil acidity affects most soil parameters such as the solubility of metallic elements, the assimilation of mineral elements by plants, the structure and activity of soil microorganisms (Brady and Weil, 2002; Kemmit et al., 2006). It is reported that soybeans adapt less well in acidic soils which may require limestone amendments in order to optimize its yield (Gigandon et al., 2005; Simon, 2005; Mouhouche, 2007, Cetiom, 2009). The studies by Kosslak and Bohlool (1985) and Lawson et al. (1995) report that nodule formation decreases with decreasing $\mathrm{pH}$. More recently, in a study conducted in Germany and Poland by Griebsch et al. (2020), it was proved that $\mathrm{pH}$ significantly affected the relative abundance of Bradyrhizobium sp and this is attested by Albareda et al. (2009) and Gazdag et al. (2015) who report that Bradyrhizobium sp prefer soil with neutral or slightly acidic $\mathrm{pH}$. All of these studies, like many others, evaluated the influence of soil acidity on the nodulation and abundance of Bradyrhizobium sp. However, how Bradyrhizobium could affect $\mathrm{N}$ allocation throughout soybean plants is still unclear. Therefore, the objective of this study is to assess the effect of Bradyrhizobium sp. on the nitrogen content of soybean leaves and seeds grown on acidic soils.

\section{Materials and Methods}

\subsection{Study sites}

Two experiments during the 2015-2016 cropping season in two agroecological zones. The first experiment (Site 1) was carried out in the experimental field of the Faculty of Agronomic Sciences of Lubumbashi University (UNILU), located at an altitude of $1250 \mathrm{~m}, 11^{\circ}$ $60869^{\prime}$ South latitude and $027^{\circ} 47692^{\prime}$ East longitude. The second experiment (Site 2) was conducted in Kipushi territory, precisely in Kaniameshi and located at $11^{\circ} 45^{\prime} 25$ "South and $27^{\circ} 16^{\prime \prime} 59$ "East and $1320 \mathrm{~m}$ altitude. The annual rainfall in these agroecological zones is around $1270 \mathrm{~mm}$ with a rainy season of 118 days, while the average annual temperature is around $20^{\circ} \mathrm{C}$ with great interannual stability. Soils of the study are characterized as Ferralsols a pH-water around 5.2 (Kasongo et al., 2013).

The biological material used consisted of four varieties of soybean (Glycine max (L) Merr) and three strains of Bradyrhizobium. Within these four soybean varieties, two (TGX 17407F and 1880-3E) were obtained at the National Institute for Agronomic Study and Research (INERA), Kipopo station, and the other two varieties were obtained from Zambia (LUKANGA variety from ZAMSEED and PAN 1867 from PANNAR). Three commercial inoculum strains of the Bradyrhizobium genus were used, namely: the Bradyrhizobium sp strain of pasty formulation, the Sojapak ${ }^{\circledR} 50$ strain of liquid formulation, and the GraphExTM strain of powder formulation. The Bradyrhizobium sp strain was supplied by the National Fertilizer and Input Service (SENAFIC) and the other two strains (Sojapak ${ }^{\circledR}$ 50 and GraphExTM) were obtained on the local market.

\subsection{Experiment setup and follow-up}

In each site, the experiment was installed following a Split-Plot setup with three replicates. In the main plot, three strains of Bradyrhizobium plus the uninoculated control and four varieties of soybean in the subplot. The combination of the different strains and varieties resulted in 16 treatments. The seedlings were made at spacings of $0.40 \mathrm{~m} \times 0.20 \mathrm{~m}$ at the rate of 2 seeds per pocket, i.e., a density of 250,000 plants per hectare. For symbiotic inoculation, a single procedure was used for all formulations to ensure that all seeds received a thin layer of the inoculant for the enhancement of biological nitrogen fixation (Gemell 
et al., 2005). All inoculations were made in the shade just before sowing in order to maintain the viability of the bacterial cells. The different formulations were used for $1 \mathrm{~kg}$ per $50 \mathrm{~kg}$ of seed for the GraphEx ${ }^{\mathrm{TM}}$ and Bradyrhizobium sp strains and $1000 \mathrm{ml}$ for $50 \mathrm{~kg}$ of seed for the Sojapak ${ }^{\circledR} 50$ strain in liquid form.

\subsection{Sample collection and laboratory analysis}

Topsoil $(0-20 \mathrm{~cm})$ samples were taken before, during (at flowering) and after experimentation for the analysis of $\mathrm{N}$. To measure the nitrogen content in the soybean plant, leaf and seed samples were taken following the treatments.

Soil $\mathrm{pH \kappa \textrm { }}$ was determined using an electronic $\mathrm{pH}$ meter in a soil solution with a ratio soil/ $\mathrm{KCl} 1 \mathrm{~N}$ of $1 / 2.5$. The organic carbon (C) was determined by the Walkley and Black method. Organic matter content was obtained by multiplying the carbon content by 1.724 . The available $\mathrm{P}$ was determined by spectrophotometry after extraction with $0.03 \mathrm{M} \mathrm{NH} 4 \mathrm{~F}$ and $0.1 \mathrm{M} \mathrm{HCl}$. Nitrogen content in soils and aerial organs (leaves and seeds) was determined by the Kjeldahl method.

\subsection{Statistical data treatments}

The comparison of the means between the two sites was performed using the analysis of variance by considering 0.05 as the significance level using the R 4.0.3 software. Figures were produced using the GraphPad Prism 9 software.

\section{Results}

\subsection{Chemical parameters}

$\mathrm{pH \kappa Cl}$ is higher $(\mathrm{P}<0.05)$ in site 2 than in site 1 (Figure 1$)$. However, both sites have a $\mathrm{pH} \mathrm{KCl}$ below 5.5. Regarding organic $\mathrm{C}(\mathrm{OC})$, organic matter $(\mathrm{OM})$, and $\mathrm{C} / \mathrm{N}$ ratio, a comparison of means shows that there is no statistically significant difference $(P>0.05)$ between the two sites. Nitrogen content is higher in site 2 compared to site 1 (respectively $0.16 \%$ against $0.11 \% \mathrm{~N})(\mathrm{P}<0.05)$. For the available $\mathrm{P}$, the content is higher in site 2 than in site $1(\mathrm{P}<$ $0.05)$. In contrast, $\mathrm{K}$ content was highest in site 1 and lowest in site $2(\mathrm{P}<0.05)$.
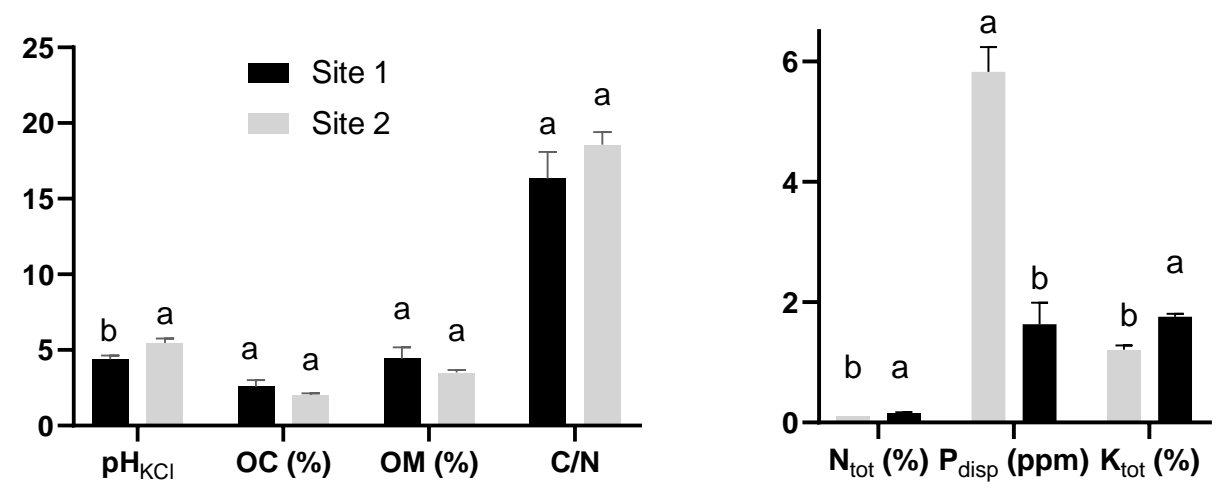

Figure 1. Some chemical parameters in the study sites. Site 1: Kasapa, Site 2: Kanyameshi

\subsection{Effects of Bradyrhizobium strains on $\mathbf{N}$ contents in soybean leaves and seeds}

It emerges from Figure 2 that the different strains of Bradyrhizobium did not induce significant effects on the total nitrogen content in the leaves $(\mathrm{P}=0.444)$ and in the seeds $(\mathrm{P}=$ 0.476) at Site 1. Regarding the nitrogen in the leaves, the result shows that the plots without inoculum show slightly low nitrogen content in the leaves although the statistical test 
did not show any significant differences. At Site 2, the different strains of Bradyrhizobium influenced the $\mathrm{N}$ content in soybean leaves $(\mathrm{P}=0.01)$. The control treatments (non-inoculated) have the lowest nitrogen content data compared to treatments inoculated with Bradyrhizobium. However, in the seeds, the result shows similarities between the strains used $(\mathrm{P}=0.925)$.
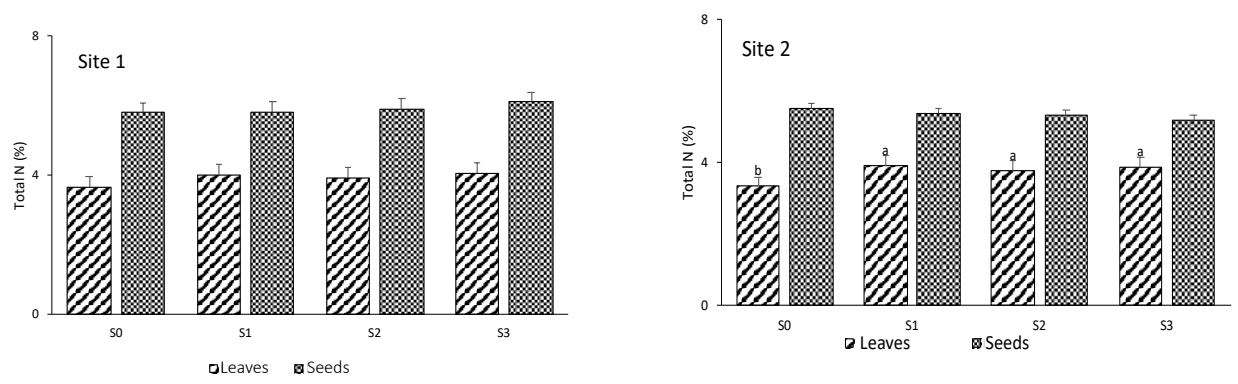

Figure 2. Effects of Bradyrhizobium strains on $\mathrm{N}$ contents in soybean leaves and seeds.

\subsection{Correlation among $\mathrm{N}$ content in soil, leaves, and seeds as well as soybean yields}

Figure 3 shows the results of the correlation between $\mathrm{N}$ contained in soils (Site 1 soil and Site 2 soil), leaves and seeds. It appears that in Site 1, N content of leaves is highly and positively correlated with the $\mathrm{N}$ content of seeds and soil at both sites $(\mathrm{P}<0.05)$. Also, $\mathrm{N}$ is highly and positively correlated with the yield and the number of nodules $(\mathrm{P}<0.05)$. Nitrogen in seeds correlates positively with yield and very positively correlates with soil $\mathrm{N}$ at Site $1(\mathrm{P}<0.05)$. Furthermore, soil $\mathrm{N}$, is positively correlated with yield and number of nodules $(\mathrm{P}<0.05)$.

At Site 2, N content of leaves is highly and negatively correlated with $\mathrm{N}$ content of seeds $(\mathrm{P}<0.05)$, but positively correlated with soil $\mathrm{N}$ at Site 1 and highly and positively correlated with yield, nodule number and soil $\mathrm{N}$ at Site $2(\mathrm{P}<0.05)$. Nitrogen content of seeds is negatively correlated with yield, number of nodules and soil $\mathrm{N}$ at Site $2(\mathrm{P}<0.05)$. Finally, soil $\mathrm{N}$ content at Site 2 is positively correlated with yield and the number of nodules.

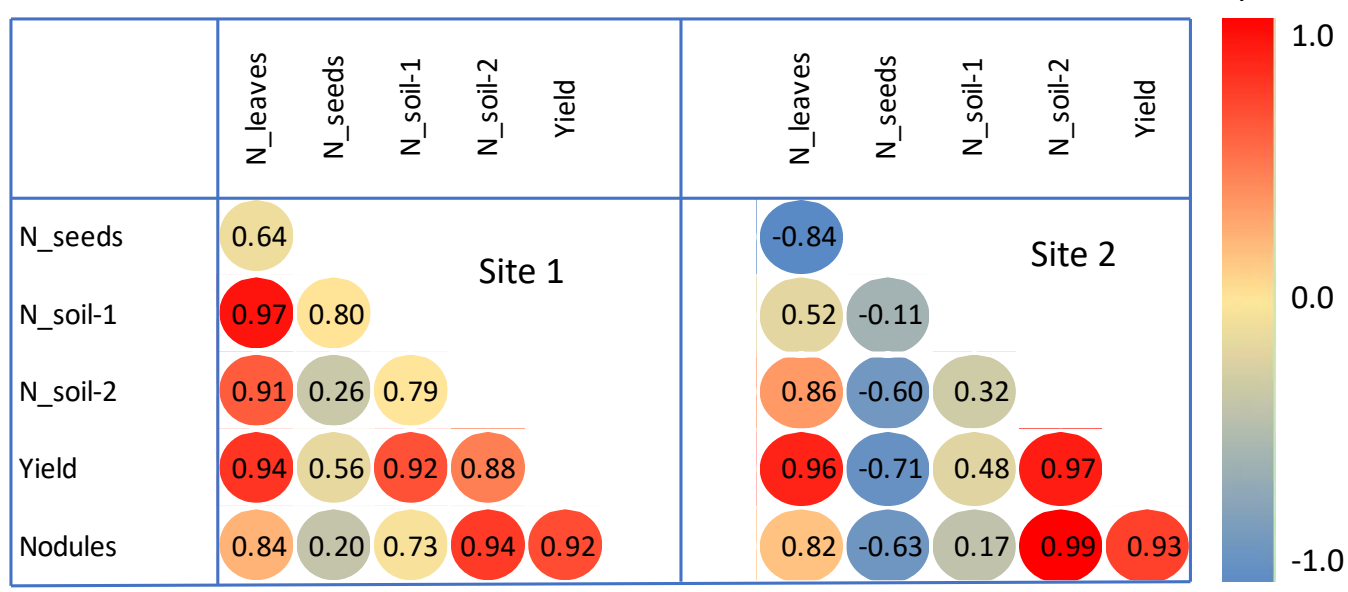

Figure 3. Correlation among $\mathrm{N}$ content in soil, leaves, and seeds as well as soybean yields at site 1 and 2. N_soil-1: nitrogen content in soils at flowering, N_soil-2: nitrogen content in soils at harvest. 


\section{Discussion}

\subsection{Chemical properties of the soils}

The obtained $\mathrm{pH \kappa сl} \mathrm{in} \mathrm{both} \mathrm{sites} \mathrm{was}<5.5$ with highest values at Kanyameshi compared to Kasapa, respectively $5.5 \pm 0.3$ and $4.4 \pm 0.26$. These results corroborate with those found by several authors for soils in the Lubumbashi region and its surroundings (Ngongo and Kasongo 2004; Ngongo and Mukalay, 2004). There were no statistically significant differences in OC content between studied sites. Mean OC content in both sites was $<3 \%$ (i.e., $2 \pm 0.0 .1$ for site 2 versus $2.6 \pm 0.4$ for site 1$)$. This low OC content corroborates the results found by Six et al. (2002), (Kemmit et al., 2006), and Muhinda et al. (2009) for soils in the tropics. Apart from the fact that tropical soils are generally low in OC, values observed in our case could be explained on the one hand by a low entry of the litter characterizing agroecosystems and on the other hand, the loss of surface layer rich in OM by erosion.

Available P content was higher at site 2 than at site 1 (respectively $5.8 \pm 0.4$ and $1.6 \pm 0.4$ ) $(\mathrm{P}<0.05)$. However, the available $\mathrm{P}$ content observed at both sites is considered to be low (Debaveye, 1985). Low P availability in tropical soils is mainly due to its retention by precipitation with free aluminum, which at a $\mathrm{pH}<5$, is extensively mobilized (Foth and Ellis, 1988; Hue et al., 2001; Pierzynsky et al, 2005; Crawford et al., 2008). For Troeh and Thompson (2005), the fixation of $\mathrm{P}$ compounds by iron and aluminium oxides, as well as their degree of insolubility, are responsible for the low availability of forms that can be assimilated by plants. Total $\mathrm{N}$ was highest at site 2 compared to site 1 (respectively $0.16 \%$ against $0.11 \%$ nitrogen) $(\mathrm{P}<0,05)$. Landon (1991) considers $\mathrm{N}$ contents higher than $0.13 \%$ as satisfactory in tropical soils. At site 2, $\mathrm{N}$ content is therefore acceptable according to Landon (1991) than in site 1.

\subsection{Effects of Bradyrhizobium strains on $\mathbf{N}$ contents in soybean leaves and seeds}

The results obtained showed that soybeans contained significantly more total $\mathrm{N}$ in both study sites compared to leaves. This is explained by the fact that the soybean contains between 30 and $45 \%$ of proteins (Cheftel et al., 1985) of which proteins are composed of $16 \%$ by N. Regarding nitrogen in the leaves, the results showed an influence of different strains of Bradyrhizobium $(\mathrm{P}=0.01)$. The control plots (non-inoculated) showed the lowest $\mathrm{N}$ content compared to plots with Bradyrhizobium strain. Statistical analysis also revealed high levels of $\mathrm{N}$ in the leaves of plants inoculated with different strains compared to the leaves of the uninoculated control. Adebayo, (1992) and Danso et al., (1988) reported that, in practice, Bradyrhizobium strains introduced into the soil are exposed to the effects of numerous ecological factors which subsequently determine their survival and effectiveness. This would explain the differences in the results obtained in this study between the strains. In addition, the success of inoculation depends not only on the strain used, but also on its ability to withstand adverse environmental conditions (Keyser and Li, 1992; Thies et al., 1991; Nazih et al., 1993) on the one hand, and on the other hand, to be able to survive in the soil as saprophytic microorganisms beyond the first month following inoculation (Gibson et al., 1982). Nutritional constraints can also limit symbiotic nitrogen fixation by affecting the survival and multiplication of rhizobia, initiation, development and nodular function as well as the growth of the host plant (Delgado et al., 1994).

\subsection{Correlation among $\mathrm{N}$ content in soil, leaves, and seeds as well as soybean yields}

The results of correlation in Figure 4, showed that in Site 1, N content of leaves is highly and positively correlated with nitrogen content of seeds and soil $(\mathrm{P}<0.05)$. Nitrogen was also highly and positively correlated with the yield and the number of nodules $(\mathrm{P}<0.05)$. Nitrogen in seeds correlates positively with yield and positively correlated with soil $\mathrm{N}$ at Site $1(\mathrm{P}<0.05)$. For soil $\mathrm{N}$ at site 1 and 2 , it correlated positively with yield and number of nodules $(\mathrm{P}<0.05)$. These results seem to be in contradiction with those found in Europe 
by Griebsch et al. (2020) who found no relationships between N supplied alone as inorganic fertilizer on nodulation and yield except when supplied in combination with P. Furthermore, Voisin et al. (2013) found that $\mathrm{N}$ supplied as mineral fertilizer slowed down nodulation and a lower yield than the control. However, the results found by Zamukulu et al. (2018) in South Kivu in DR Congo and Ahmed et al. (2006) in Pakistan found that yield and nodulation increased with increasing doses of mineral nitrogen fertilizer indicating a positive relationship between soil $\mathrm{N}$ and nodulation. The difference observed between our results and those obtained by certain authors such as Voisin et al. (2013) and Griebsch et al. (2020), could be explained by the fact that these different studies were described under different conditions. Indeed, Mendes et al. (2003) report that the soybean response to nitrogen depends on several factors such as the efficiency of the Bradyrhizobium strain, the soybean variety and the initial soil nitrogen in the event of nitrogen supply in the form of mineral fertilizer.

\section{Conclusions}

This study aimed at assessing the effect of Bradyrhizobium japonicum on $\mathrm{N}$ content of soybean leaves and seeds cultivated on acidic soils. We found that the studied soils are acidic and generally poor in nutrients. The different strains of Bradyrhizobium did not induce significant effects on the total $\mathrm{N}$ content in the leaves and seeds in site 1 (Kasapa) on the other hand in site 2 (Kanyameshi) only N content in the leaves was influenced. However, in both sites, it was found that the plots without inoculum had lower means compared to plots with inoculum. Nitrogen content in the soil, which varied among sites, positively influenced yield and nodulation. Thus, the effectiveness of the soybean-rhizobium symbiosis and its influence on the allocation of $\mathrm{N}$ through plants, strongly depend on the chemical characteristics of the soil and particularly on the initial levels of $\mathrm{N}$ in the soils.

Author Contributions: Conceptualization, B.T.K-B., and A.K.L; methodology, T.K-B., E.K.L and A.K.L; software, J.L.B and B.T.K-B.; validation, E.K.L and A.K.L.; formal analysis, B.T.K-B. and A.B.N.; investigation, A.B.N, F.K.K, and B.T.K-B.; resources, B.T.K-B.; data curation, B.T.K-B. and F.K.K.; writing - original draft preparation, B.T.K-B. and J.L.B.; writing - review and editing, all authors.; supervision, E.K.L. and A.K.L.; All authors have read and agreed to the published version of the manuscript.

Funding: This research received no external funding

Data Availability Statement: Data used in this study can be obtained from the corresponding author upon a reasonable request.

Conflicts of Interest: The authors declare no conflict of interest.

\section{References}

Adebayo A., 1992. Nitrogen fixation and management pratices for its enhancement in tropical agriculture. In comm. 5th Conference of AABNF. Rabat (Morocco), 14-19pp

Albareda M., Rodríguez-Navarro D. N., Temprano F. J., 2009. Soybean inoculation: Dose, N fertilizer supplementation and rhizobia persistence in soil. Field Crops Research, 113, 352-356.

Ahmed Z. I., Anjum M. S., Rauf C. A., 2006. Effect of Rhizobium inoculation on growth and nodule formation of green gram. International Journal of Agriculture and Biology, 8, 235-237.

Mendes I. C., Hungria M., Vargas, M. A. T., 2003. Soybean response to starter nitrogen and Bradyrhizobium inoculation on a Cerrado Oxisol under no-tillage and conventional tillage systems. Revista Brasileira de Ciência do Solo, 27, 81-87.

Amarger N., 2001. Rhizobia in the Field. In: Sparks D.L. (Ed): Advances in Agronomy. Academic Press, 73, 109-136

Brady N.C., Weil R.R., 2002. The nature and properties of soils. 13th ed. Upper Saddle River, NJ, USA: Pearson Education Inc.

Cetiom 2009. Les points-clés de la conduite du soja. Brochure. Cetiom (Ed). 6p.

Cheftel J.C., Cuq J.L. et Lorient D., 1985. Protéines alimentaires. In : Biochimie - Propriétés fonctionnelles - Valeur nutritionnelle Modification chimique. Technique et Documentation - Lavoisier, Paris, 156 -192. 
Crawford T.W., Singh Jr.U., Breman H., 2008. Solving agricultural problems to soil acidity in Central Africa's Great Lakes Region. Kigali, Rwanda.

Danso S.K.A., Labandera C., Pastorini D. et Curbalo C., 1988. Nitrogen fixation in two-year old white clover-Fescue pasture. Influence of nitrogen fertilization. Soil Biochem., 20, 261-262.

Debaveye J., 1985., Handbook for data Interpretation. Soil survey technical document, 2, 125 p.

Diop I., Kane A., Krasova-Wade T., Sanon K.B., Houngnandan P., Neyra M., Kandioura N., 2013. Impacts des conditions pédoclimatiques et du mode cultural sur la réponse du niébé (Vigna unguiculata L. Walp.) à l'inoculation endomycorhizienne avec Rhizophagus irregularis. Journal of Applied Biosciences, 69, 5465 - 5474

Foth H.D., Ellis B.G, 1988. Soil fertility Muchigan Statte University 212 p

Gazdag O., Ködöböcz L., Szili-Kovács T., Murányi A., 2015. Characterization of the efficiency of soybean inoculation. Agrokémia és talajtan, 64, 453-465

Gemell L. G., Hartley E. J., Herridge D.F., 2005. Point-of-sale evaluation of preinoculated and custom-inoculated pasture legume seed. Australin Journal of Agricultural Research, 45, 161-169.

Gibson A. H., Dreyfus B. L., Dommergues Y. R., 1982. Nitrogen fixation by legumes in the tropics. In: Microbiology of tropical soils and plant productivity (YR Dommergues, HG Diem, eds) Martinus Nijhoff/Dr W Junk publishers, The Hague, 37-73.

Gigandon C., Jouffret P., Gagnant M., Jung L., Harel N., 2005. Les points clés de la conduite du soja. Cetiom février, 4, 24p.

Griebsch A., Matschiavelli N., Lewandowska S., Schmidtke K., 2020. Presence of Bradyrhizobium sp. under Continental Conditions in Central Europe. Agriculture, 10, 446p.

Herliana1 O., Harjoso T., Anwar1 A.H.S., Fauzi1 A., 2019. The Effect of Rhizobium and N Fertilizer on Growth and Yield of Black Soybean (Glycine max (L) Merril). Earth and Environmental Science, 255p.

Hue H. Q., He J. Z., Li X.Y., Lia F., 2001. Effect of several organic acids in phosphate absorption by variable charge soils of central china, department of Resources, Environment and Agrochemistry, Huazzhong Agricultural University, Wuhan 430070, China. Environment International, 26, 353-358.

Javaheri F. Baudoin G.J.H., 2001. Le soja : 860-882. In : Raemaekers (Eds) : Agriculture en Afrique Tropicale, DGCI, Bruxelles, Belgique : 1634 pp.

Kasongo L.M.E., M.T. Mwamba M.P. Tshipoya M.J. Mukalay S.Y. Useni K.M. Mazinga K.L., Nyembo., (2013). [Response of soybean (Glycine max L. (Merril) to the green biomass of Tithonia diversifolia (Hemsley) A. Gray used as organic fertilizer on a Ferralsol in Lubumbashi, DR Congo]. J. Applied Biosci., 63: 4727-4735.

Kemmitt S.J., Wright D., Goulding K.W.T. Jones D.L., 2006. pH regulation of carbon and nitrogen dynamics in two agricultural soils. Soil Biol. Biochem., 38, 898-911.

Kosslak R.M. Bohlool B.B., 1985. Influence of environmental factors on interstrain competition in Rhizobium japonicum. Appl. Environ. Microbiol., 49, 1128-1133.

Landon J.R., 1991. Booker tropical soil manual. A handbook for soil survey and agricultural land evaluation in the tropics and subtropics. Oxon, UK: Booker Tate Limited; Harlow, Essex, UK: Longman.

Lawson, Y.D., Muramatsu K., Nioh I., 1995. Effect of organic matter on the growth, nodulation, and nitrogen fixation of soybean grown under acid and saline conditions. Soil Sci. Plant Nutr. 41, 721-728.

Mbonigaba M.J.J., Nzeyimana I., Bucagu C., Culot M., 2009. Caractérisation physique, chimique et microbiologique de trois sols acides tropicaux du Rwanda sous jachères naturelles et contraintes à leur productivité. Biotechnol. Agron. Soc. Environ. 13, 545-558.

Mouhouche B., 2007. Manuelle sur la conduite de la culture de soja (G. max. L. Merr.) réalisé par la société agro-industrie Algerie, $234 \mathrm{p}$.

N'gbesso M. F-P., Fondio L., Dibi B. E. K., Djidji H.A., Kouame C. N., 2013. Étude des composantes du rendement de six variétés améliorées de niébé [Vigna unguiculata (L.) Walp]. Journal of Applied Biosciences, 63, 4754 - 4762.

Nazih N., Sen D., Weaver R.W., 1993. Population densities of Clover rhizobia in Texas pastures and responses to liming. Biol. Fertil. Soils, $15: 45-49$.

Ngongo L. M., Kasongo L. M., 2004. Le niveau de la matière organique dans quelques sols de la périphérie de Lubumbashi et Likasi in Ann.Fac.Sc. Agro., 1, 119-123. 
Ngongo L. M., Mukalay M. J., 2004. Le rapport limon/argile : un critère d'estimation du stade d'altération des sols tropicaux in Ann.Fac.Sc. Agro., 1, 129-136.

Pierzynsky G. M., Sims J. T., Vance G. F., 2005. Soils and environmental quality. 3rd ed. Taylor Francis, London.569pp.

Sanchez P.A., 2002. Soil fertility and hunger in Africa. Science, 295, 2019-2020.

Simon J-P., 2005. Plantes utilisées par l’Homme : les legumineuses. Préparés pour le département de Sciences biologiques. Université de Montréal.

Six J., Feller C., Denef K., Agie S. M., Sà J. C. d. M. et Albrecht A., 2002. Soil organic matter, biota and aggregation in temperate and tropical soils - Effects of no-tillage. Agronomie, 22,755-775.

Smil V., 2002. Biofi xation and nitrogen in the biosphere and in global food production. In : Nitrogen fixation : global perspectives. T.M. Brogan et al. ed., CAB International, New York, 7-9.

Soussou S., 2013. Adaptation de la symbiose Fabacées-rhizobium aux sites miniers : Absorption du zinc par Anthyllis vulneraria et analyse de la diversité des bactéries symbiotiques d'Hedysarum coronarium. Thèse de doctorat, Institut Supérieur Agronomique De Chott-Meriam, 230p.

Thies J. E., Singleton P. W Bohlool B. B., 1991. Influence of the size of indigenous rhizobial populations on establishment and symbiotic performance of introduced rhizobia on field-grown legumes. Appl. Microbiol. Environ., 57, 19-28.

Troeh F.R. Thompson L.M., 2005. Soils and soil fertility. 6th ed. Oxford, UK: Blackwell Publishing.

Voisin A.-S., Guéguen J., Huyghe C., Jeuffroy M.-H., Magrini M.-B., Meynard J.M., Mougel C., Pellerin S., Pelzer E., 2013. Les légumineuses dans l'Europe du XXième siècle : Quelle place dans les systèmes agricoles et alimentaires actuels et futurs ? Quels nouveaux défis pour la recherche? Innov. Agron., 30, 283-312.

Zamukulu P., MondoJ., Kalumire P., Ayagirwe R., Bagula J., Karume K., Katunga D., Baboy L., Njukwe E., Nabahungu L., Lubobo A., Ndjadi S. Mushagalusa G., Réponse du soja (Glycine max L.) à des doses croissantes du DAP et Urée au Sud-Kivu, RD Congo. Journal of Applied Biosciences, 122, 12309-12318. 